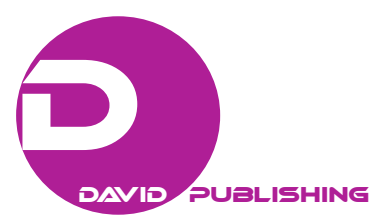

\title{
Famine, Affluence, and Hypocrisy
}

\author{
Keith Burgess-Jackson \\ The University of Texas at Arlington, Arlington, Texas, USA
}

\begin{abstract}
The standard view among philosophers is that an arguer's hypocrisy (understood as failure to practice what one preaches) has no bearing on either the merits of his or her argument or the acceptability of the argument's conclusion. I challenge this view. Using the case of Peter Singer, who has famously argued for a moral obligation to relieve famine, but who does not, by his own admission, live in accordance with the standard he espouses, I explain why (and how) an arguer's hypocrisy matters. If I am correct, then the standard view of the relation between arguer and argument must be revised.
\end{abstract}

Keywords: Peter Singer (1946-), famine, affluence, morality, hypocrisy, authenticity, integrity, argumentation

\section{Introduction}

The only possible criticism of a philosophy, the only criticism that proves anything at all, is trying to see if one can live by it (Nietzsche, 1990, p. 220).

There would be something incoherent about living a life where the conclusions you came to in ethics did not make any difference to your life. It would make it an academic exercise. The whole point about doing ethics is to think about the way to live. My life has a kind of harmony between my ideas and the way I live. It would be highly discordant if that was not the case (Peter Singer, quoted in Toolis, 1999).

Peter Singer’s 1972 essay, “Famine, Affluence, and Morality” (Singer, 1972), is one of the most widely reprinted essays in the history of philosophy. ${ }^{1}$ It is justly famous, not only for broaching the topic of duties to the impoverished, but for doing so in a careful, dispassionate, philosophically serious way. (It doesn't hurt that Singer is an elegant writer. ${ }^{2}$ ) Many words have been written both in support of and in opposition to Singer's reasoning, and I do not propose to add to the number here. ${ }^{3}$ My concern lies elsewhere-with the relevance, if any, of Singer's conduct to his argument. One of the most common questions posed to me when I lecture on Singer's essay (which I have done many times) is whether he lives up to his own high standards of behavior. Students ask, "Does Singer practice what he preaches?” or (accusingly) “How much money does Singer donate to famine relief?”

Keith Burgess-Jackson, J.D., Ph.D., is Associate Professor of Philosophy in the Department of Philosophy and Humanities at the University of Texas at Arlington. He is the author of many books, articles, book chapters, encyclopedia entries, and book reviews in logic, ethics, philosophy of religion, biomedical ethics, philosophy of law, and social and political philosophy.

\footnotetext{
1 According to Singer (writing in 2016), "An incomplete list of anthologies in which [the essay] has been reprinted runs to fifty" (Singer, 2016a, p. xii). Singer has reprinted the essay at least three times: in Singer, 2001; Singer, 2002; and Singer, 2016a.

2 “The impact of Peter Singer's writing is due as much to his gift for moral rhetoric as to the quality of his arguments. Reading his 1972 paper 'Famine, Affluence, and Morality,' one felt intellectual interest in the argument, but also guilt for not having contributed more money to relieve starvation. Many otherwise sober citizens, after reading his 1975 book Animal Liberation, became vegetarians. It is difficult to say just how this effect is achieved. There is no preaching; somehow a sense of moral urgency is conveyed through the statement of the theoretical arguments themselves. I know of no other writer whose work combines intellectual analysis and moral persuasion so compellingly” (Rachels, 1981, p. 45).

${ }^{3}$ One prominent critic is Kekes, 2002.
} 
Until recently, I gave the stock answer to these questions: that whether Singer practices what he preaches-i.e., whether Singer is a hypocrite - is irrelevant to his argument. I explain that there is a difference between people and (their) arguments. Good people can make bad arguments, and bad people good. ${ }^{4}$ Suppose Adolf Hitler (the quintessential bad person) reasoned as follows:

1. All men are mortal.

2. Socrates is a man.

Therefore,

3. Socrates is mortal.

Nobody but a crank would dispute Hitler's personal badness, but we would have to admit (however grudgingly) that in this case Hitler made a sound argument, for (1) his premises are true and (2) his conclusion follows logically from them. I am not suggesting that being a hypocrite is in the same league as being a genocidal maniac - only that, however bad a person is, as a person, he or she is still capable of arguing soundly, or of producing a sound argument. It follows that even if Singer is a hypocrite with respect to his famine-relief argument, and even if this fact about him makes him a bad person, his badness has no bearing on the quality of his famine-relief argument. His argument, we might say, stands or falls on its own (intrinsic) merits, not on such accidents as who made it or when, where, why, how, or to whom it was made.

This, I suspect, is how most instructors respond (or would respond) to student inquiries about Singer's supposed hypocrisy. But I have come to believe that the response is curt. Certainly, some of my students find it unimpressive. They feel as though, in (1) distinguishing between people and (their) arguments and (2) claiming that evaluations of the former are irrelevant to evaluations of the latter, I have somehow changed the subject or evaded the question. (A select few of them may believe that I am protecting a fellow philosopher from criticism.) I think it is time for philosophers to reflect more thoroughly on the concept of hypocrisy and its relation to argumentation. One benefit of this reflection may be fewer dissatisfied, and ultimately fewer unedified, students.

So let us ask, point-blank: Is Peter Singer a hypocrite, as some (many) students suspect? That is, does Singer fail to live up to the high standard of behavior that he propounds in his famous essay (and elsewhere)? I will make a case for an affirmative answer to this question. If you are unpersuaded by the case I make, then you should suppose, for the sake of argument, that Singer is a hypocrite. I want to ask what-if anything-follows from this supposition. Some of what I go on to say is peculiar to Singer and his argument, while other points I make apply more generally, to other people and other arguments. I focus on Singer because (1) his case is likely to be familiar to readers of this journal and (2) those same readers are likely to have fielded the sorts of questions about Singer that $I$ have fielded over the years.

I begin the essay, in Part 2, with a discussion, and eventually a reconstruction, of Singer's argument, for it is the bold and provocative nature of the conclusion of this argument that gives rise to the suspicion that Singer is a hypocrite. In Part 3, I discuss briefly what it would mean for Singer to fail to live up to the high standard of behavior prescribed by his conclusion. This requires an analysis of the concept of hypocrisy. I believe (and show) that there are three distinguishable types of hypocrisy, which I call "advocacy hypocrisy," "criticism hypocrisy," and "projection hypocrisy.” In Part 4, I make a case, through meticulous documentation, that

\footnotetext{
${ }^{4}$ Or, as Morris Cohen and Ernest Nagel put it, "Bad men may be logically consistent” (Cohen \& Nagel, 1962, p. 21). Just as a good (bad) president is not necessarily a good (bad) parent, a good (bad) arguer is not necessarily a good (bad) person. "Good” and "bad" are relative terms, like "large" and "small." A large mouse is not a large animal.
} 
Singer is a hypocrite of all three types. In the main section of the essay, Part 5, I explain precisely why (and how) Singer's hypocrisy matters to his argument, concluding that, because the situation is more complicated than initially believed, the stock response by instructors to their students is inadequate. In other words, students who query Singer's hypocrisy are, or may be, on to something. Their questions, therefore, should not be dismissed as (1) category mistakes (i.e., crude conflations of people and [their] arguments), (2) impertinence, (3) evasions of an uncomfortable topic by shifting the focus from argument to arguer, (4) tu quoque fallacies, ${ }^{5}$ or (5) confusion.

Perhaps, mirabile dictu, instructors have something to learn from their students, if only they (the instructors) would listen attentively and take the time charitably to reconstruct their students' arguments. This is, after all, how we treat our philosophical colleagues, even when we believe them to be mistaken about the matter at hand. It is also how we expect to be treated when we make arguments of our own.

\section{Singer's Argument}

The philosophers have only interpreted the world, in various ways; the point, however, is to change it (Marx, 1845/1888, Thesis 11 [italics in original]). ${ }^{6}$

The second thing that ethics is not is an ideal system that is all very noble in theory but no good in practice. The reverse of this is closer to the truth: an ethical judgment that is no good in practice must suffer from a theoretical defect as well, for the whole point of ethical judgments is to guide practice (Singer, 2011, p. 2). ${ }^{7}$

Singer believes that each of us (presumably, each moral agent) "ought, morally, to be working full time to relieve great suffering of the sort that occurs as a result of famine or other disasters" (Singer, 1972, p. 238). He has also written that "we ought to prevent as much starvation as we can, up to the point at which we can do no more without sacrificing something of comparable moral importance” (Singer, 1977, p. 37). Lest anyone doubt the stringency of this requirement, Singer elaborates:

This means that instead of spending our available income on new clothes, cars, dinners in expensive restaurants, or other items that cannot be compared, in moral importance, to saving someone from starving to death, we ought to give our money to those who can most effectively use it to prevent starvation (Singer, 1977, p. 37). ${ }^{8}$

Singer doesn’t just believe this proposition; he has argued for it for nearly half a century, hoping thereby to persuade others (his readers, listeners, and viewers) to share his belief (and, presumably, to act on it). In 2016, he republished his 1972 essay with no changes, implying that he continues to accept and endorse its conclusion. Here are some representative statements of the thesis, by Singer, over the years:

- $\quad$ 1979: "[W]e are obliged [i.e., morally obligated] to give to the point at which by giving more we sacrifice something of comparable moral significance” (Singer, 1979, p. 180).

- $\quad$ 1999: “[T]he formula is simple: whatever money you're spending on luxuries, not necessities, should be given away” (Singer, 1999a).

- 2010: "[Y]ou must keep cutting back on unnecessary spending, and donating what you save,

\footnotetext{
5 “Another form of irrelevance is the tu quoque, or 'two wrongs' technique. If some action or view of one's own is criticized, one may reply by attacking some action or view of one’s critic that is equally hard to defend” (Mackie, 1967, p. 177).

6 "In the eleventh thesis, Marx, besides advocating revolution, is making the point that it is only insofar as a theory serves as the basis for practice that it can be shown to be justified” (Altman, 1983, p. 233).

7 “The point of practical ethics is not simply to understand the world, but to change it” (Jamieson, 1999, p. 6 [explaining Singer's view]). Singer's work, in other words, is "revisionary," and in some cases revolutionary.

8 Two years after writing this sentence, Singer pointed out that "For most of us, with commonsense views about what is of moral significance, this would mean a life of real austerity" (Singer, 1979, p. 180). “Austerity," in everyday speech, means "extreme plainness and simplicity of style or appearance” (New Oxford American Dictionary, 2010, p. 107 [second definition]).
} 
until you have reduced yourself to the point where if you give any more, you will be sacrificing something nearly as important as a child's life-like giving so much that you can no longer afford to give your children an adequate education” (Singer, 2010, p. 18).

- 2016: "[W]e ought to be preventing as much suffering as we can without sacrificing something else of comparable moral importance” (Singer, 2016a, p. 22).

Singer is aware that this is a demanding standard, inasmuch as it requires "reducing ourselves to the level of marginal utility” (Singer, 1972, p. 241). For readers who do not know what this means, Singer explains: the level of marginal utility is "the level at which, by giving more, I would cause as much suffering to myself or my dependents as I would relieve by my gift” (Singer, 1972, p. 241). How does this requirement play out, in practice? In a widely reprinted essay, first published in the New York Times in 1999, Singer elaborated:

In the world as it is now, I can see no escape from the conclusion that each one of us with wealth surplus to his or her essential needs should be giving most of it to help people suffering from poverty so dire as to be life-threatening. That's right: I'm saying that you shouldn't buy that new car, take that cruise, redecorate the house or get that pricey new suit. After all, a \$1,000 suit could save five children's lives (Singer, 1999a [emphasis added]).

Singer went on to say that since the typical American household "spends around \$30,000 annually on necessities," all income above that amount should be donated "to help the world’s poor.” A household "making $\$ 100,000$ could cut a yearly check for $\$ 70,000$ ” (Singer, 1972, p. 241). Presumably, a household making $\$ 500,000$ a year should cut a yearly check for $\$ 470,000$, and a household making $\$ 1,000,000$ a year should cut a yearly check for $\$ 970,000$.

You may think that this standard is excessively demanding, but, according to Singer, it is not. In 2001, he wrote, defiantly, that "ethics can be very demanding" (Singer, 2001, p. xix), the implication being that the demands made by his moral principle are not excessive. In 2010, he admitted that his writings on famine relief present "a very demanding — some might even say impossible—standard of ethical behavior" (Singer, 2010, p. xiii). ${ }^{9}$ But he has clung to that standard. In 2016, he pointed out that his 1972 essay "leads to the uncomfortable conclusion that very few of us are living fully ethical lives” (Singer, 2016a, p. xvii).

How does Singer arrive at such a "radical" (his term) conclusion, one that goes against what many otherwise decent people believe? He does so with the following argument (expressed in the first person, since each of us is supposed, or invited, to reason in this way):

1. If it is in my power to prevent something very bad from happening, without thereby sacrificing anything morally significant, I ought to do it (i.e., to prevent it, or take steps to prevent it).

2. Suffering and death from lack of food, shelter, and medical care are very bad.

3. It is in my power to prevent suffering and death from lack of food, shelter, and medical care without thereby sacrificing anything morally significant.

Therefore,

4. I ought to prevent suffering and death from lack of food, shelter, and medical care (i.e., I have a moral obligation to relieve as much famine as I can, as long as, in doing so, I don't sacrifice anything morally significant) (from 1,2 , and 3).

The first premise of Singer's argument can be strengthened (i.e., made to impose a more stringent moral obligation) in two ways:

\footnotetext{
${ }^{9}$ He went on to say that his argument has “radically demanding implications” (Singer, 2010, p. 19 [emphasis added]).
} 
- By replacing the phrase "morally significant" with "of comparable moral importance." Not all morally significant things are comparable to suffering and death. (Keeping a promise-even a promise to take one's child to an amusement park-is morally significant, but few would claim that it is of comparable moral significance to saving a life.) So, if we changed "morally significant" to "of comparable moral importance (or significance)," it would have the effect of strengthening/enlarging our moral obligations. Singer claims that even the weak premise (the premise as it stands in my reconstruction) requires vast changes in our behavior.

- By omitting the word "very." The first premise of Singer's argument generates a moral obligation only when the state of affairs in question is very bad. Presumably, there are bad states of affairs that are not very bad states of affairs. So, if we took the word "very" out, it would have the effect of strengthening/enlarging our moral obligations; they would extend not only to very bad states of affairs, but to bad states of affairs. Note: Since suffering and death are very bad as well as bad, the change does not affect Singer's argument for famine relief. It would, however, affect other arguments, with different conclusions.

To illustrate the two versions of the principle, consider the following: I promise my child a college education. Keeping this promise-keeping any promise-is morally significant, but not morally comparable to the alleviation of suffering and the prevention of premature death. So, with the weak premise, I am not obligated to relieve famine; with the strong premise, I am.

Singer is clear beyond peradventure that the strong version of the principle is the correct version-and therefore the one he accepts. In his 1972 essay, he wrote:

It will be recalled that earlier I put forward both a strong and a moderate version of the principle of preventing bad occurrences. The strong version, which required us to prevent bad things from happening unless in doing so we would be sacrificing something of comparable moral significance, does seem to require reducing ourselves to the level of marginal utility. I should also say that the strong version seems to me to be the correct one (Singer, 1972, p. 241 [emphasis added]).

In 1977, by which time Singer could have reconsidered and weakened his claim, he repeated it: "I think the strong version is defensible, and I shall defend it shortly" (Singer, 1977, p. 37). In reply to the objection that advocating such a strong principle will (or may) be counterproductive, he doubled down: "[W]e ourselves— that is, those of us who accept the strong version - would know that we ought to do more, and we might actually give more than we urged others to give” (Singer, 1977, p. 48). Singer appears to be making a distinction between (1) accepting a proposition and (2) advocating a proposition. Those (such as Singer) who accept (and act upon?) the strong principle might advocate (to those who are morally weaker?) the moderate principle.

Two years later, in 1979, Singer made the point explicitly: "Of course we ourselves-those of us who accept the original argument, with its higher standard—would know that we ought to do more than we publicly propose people ought to do, and we might actually give more than we urge others to give" (Singer, 1979, p. 180). The goal, for Singer, is to induce action in behalf of the poor. He is willing to make whichever argument he thinks most likely to succeed in achieving this goal. Since (it is plausible to think) more people accept the moderate principle than accept the strong principle, more people are likely to be persuaded by the argument with the moderate principle than are likely to be persuaded by the argument with the strong principle.

By 1999, Singer appeared to be having concerns about the excessive stringency of his moral standard:

On my view, I could recognize that if I were totally committed to doing what I ought to do, I would give away my 
wealth up to the point indicated in my [1972] article; but at the same time I may, without any irrationality, choose to be less than totally committed to doing what I ought to do. My own interests, or those of my family, may counteract the demands of morality to some degree, and I may think it reasonable to give in to them, while recognizing that it is morally wrong for me to do so (Singer, 1999b, p. 309).

This paragraph is puzzling. It may seem as though Singer is retreating to the moderate version of his principle, or even to something weaker than that, but the final clause suggests that he continues to accept the strong version. What is one to make of this paragraph?

One interpretation is that Singer now (as of 1999) acknowledges that moral considerations are only one type of consideration when it comes to the rationality (or reasonableness) of action. It may be rational (reasonable), all things considered, or at least not irrational (unreasonable), all things considered, to act wrongly. Another possibility is that Singer now believes that there is only a (rebuttable) presumption in favor of doing what one ought. This interpretation is suggested by the words "totally committed." Is Singer suggesting that one may be less than totally committed to morality (i.e., to doing what one ought)? Is he suggesting that one may, from time to time, "take a moral holiday" (Hare, 1981, p. 57)? ${ }^{10}$ Is the idea that one ought to do what morality requires unless and until a weightier reason, moral or otherwise, comes into play? We shall revisit this puzzling paragraph later in the essay, when we discuss the relevance of Singer's supposed hypocrisy to his famine-relief argument.

In the third edition of Practical Ethics, published in 2011, Singer returns to his advocacy of the strong version of the principle. He writes: "If we can prevent something bad without sacrificing anything of comparable significance, we ought to do it” (Singer, 2011, p. 200). He also acknowledges there that his moral standard "demands impartial concern" (Singer, 2011, p. 211). This would seem to negate, or at least call into question, what he said in 1999 about the permissibility of giving greater weight to one's own interests or to the interests of one's family, both of which are forms of partiality. Finally, by republishing his 1972 essay in 2016, Singer implies that he continues to accept, if not also to advocate, the strong version of the principle. Each of us, he says, "ought, morally, to be working full time to relieve great suffering of the sort that occurs as a result of famine or other disasters” (Singer, 1972, p. 238). ${ }^{11}$

\section{Varieties of Hypocrisy}

"His moral life,” said Dumont, “is as beautiful as his intellectual.” Never did any philosopher better conform his life to his doctrines (Atkinson, 1905, p. 209, quoting Bentham’s friend and collaborator, Etienne Dumont, who was speaking of Bentham [footnote omitted]).

Discussion . . . is not enough. What is the point of relating philosophy to public (and personal) affairs if we do not take our conclusions seriously? In this instance, taking our conclusion seriously means acting upon it (Singer, 1972, p. 242). ${ }^{12}$

As ordinarily understood, hypocrisy is "the assumption or postulation of moral standards to which one's own behavior does not conform; dissimulation, pretense” (The Oxford American Dictionary and Language Guide,

\footnotetext{
${ }^{10}$ One takes a moral holiday when one allows one's prima facie moral principle to be overridden by a non-moral (for example, an aesthetic) principle. See Hare, 1981, pp. 59-60. Morality, for Hare, is overriding, so, in his view, there are no moral holidays.

11 One reviewer has written that Singer "equates moral decency with an almost monkish renunciation of material goods, popular entertainment, cultivated pleasures, and devotion to the special care of one's friends and family” (Berkowitz, 2000, p. 27).

12 This quotation encapsulates Singer's approach to ethics, as Sylvia Nasar (1999) explains: "In 1971 he [Singer] went to Oxford to study philosophy and decided that to be taken seriously, philosophical conclusions had to be reflected in action." Note the title of Singer’s 1979 book: “Practical Ethics.” The emphasis is on practice (action), not on theory (contemplation).
} 
1999, p. 480 [first definition]). ${ }^{13}$ In 1988, when it transpired that televangelist Jimmy Swaggart, who had for years railed against adultery and prostitution, was himself an adulterer and a frequenter of prostitutes, there was no hesitation in labeling him a hypocrite. Those who preach against the use of fossil fuels while driving gas-guzzling vehicles or jetting from place to place in chartered airplanes are hypocrites. ${ }^{14}$ There are many other examples of hypocrisy, not only among celebrities and politicians ("the rich and famous"), but among ordinary people. Most of us can name a hypocrite or two (or three) if asked to do so. Some of us are hypocrites.

The simplest type of hypocrisy consists in not practicing what one preaches. Let us call this "advocacy hypocrisy," for it involves advocating ${ }^{15}$ a doctrine, or standard of behavior, to which one does not conform. It is a species of pretense. ${ }^{16}$ A second type of hypocrisy involves criticizing ${ }^{17}$ or blaming others for not living up to one’s own (that is, the hypocrite’s) moral standards. Let us call this “criticism hypocrisy." ${ }^{18}$ Finally, there is

\footnotetext{
13 The New Oxford American Dictionary (2010, p. 857) defines "hypocrisy" as "the practice of claiming to have moral standards or beliefs to which one's own behavior does not conform; pretense.”

14 "Needless to say, Hollywood offers nearly limitless opportunities for anyone seeking to expose hypocrisy in the lifestyles of the rich and progressive. Laurie David, who dedicates herself to fighting for improved fuel-economy standards and reviles the owners of SUVs as terrorist enablers, gives herself a pass when it comes to chartering one of the most wasteful uses of fossil-based fuels imaginable: a private plane. (She’s not just a limousine liberal; she’s a Gulfstream liberal.)” (Alterman, 2004, p. 78).

15 “Advocate” (verb) means "publicly recommend or support” (New Oxford American Dictionary, 2010, p. 24). As this definition makes clear, it is of the essence of hypocrisy that the standard in question be publicized or propounded. Hypocrisy is failure to practice what one preaches; it is not (merely) failure to practice (or act upon) what one believes.

${ }^{16}$ There is a substantial philosophical literature on hypocrisy. Here (in chronological order by date of publication) is a sampling:
}

- " $\quad[T]$ he peculiarity of hypocrisy lies in the fact that the hypocrite is condemned by reference to his own avowed standards of proper conduct. One typical situation is this. A person is known to have endorsed moral, social, religious or political ideals, yet he himself violates these" (Szabados, 1979, p. 197).

- "[T] life if he only pretends to others that he is so committed. The hypocrite pretends to live by certain standards when in fact he does not” (Taylor, 1981, pp. 144-145).

- "A hypocrite is one who pretends to be better than she is, given a norm or set of expectations within a domain in which sincerity really matters” (Kittay, 1982, p. 281).

- “[T]he most typical case of hypocrisy” is one in which "the words suggest something morally fine but the deeds don’t match up to the high quality of the words" (Turner, 1990, p. 267).

- A "central feature" of hypocrisy is "the preaching of ideals that one fails to live up to oneself, even if the failure is in inner motive rather than action” (Benn, 1993, p. 225).

- " $[\mathrm{N}]$ ot practicing what one preaches while pretending to conform to the preaching” is "a clear case of hypocrisy” (Smilansky, 1994, p. 73).

- "[P]aradigmatic hypocrites are persons who by mismatch between judgments and actions, have undermined any claim they have to act as a moral authority” (Isserow \& Klein, 2017, p. 201 [italics in original]).

17 "Criticize" (verb) means "indicate the faults of (someone or something) in a disapproving way" (New Oxford American Dictionary, 2010, p. 410 [first definition]).

18 "Hypocrites, in calling attention to the moral lapses of another person, thereby lead their interlocutors to believe that they are free of similar lapses themselves" (Wallace, 2010, p. 316). Wallace goes on to say that "one is not entitled to chastise another for things that one does oneself” (p. 317 [italics in original]). He calls this "hypocritical moral address" (p. 323). It has two forms: blaming people for doing things that we ourselves have done, and blaming people for failing to do things that we ourselves have failed to do. Roger Crisp and Christopher Cowton call this "hypocrisy of blame." It consists, they say, "in moral criticism of others by someone with moral faults of their [sic] own” (Crisp \& Cowton, 1994, p. 345).

Daniela Dover has recently argued that "there is nothing [morally] wrong with hypo-criticism in itself” (Dover, 2019, p. 407). Hypo-criticism (her neologism) is the "behavioral pattern" consisting of (1) criticizing someone for performing an act of a certain type while (2) performing an act of that (very) type (see p. 389). Dover's "hypo-criticism” corresponds to what I am calling "criticism hypocrisy." Dover admits that her view is not widely held among philosophers (indeed, "philosophers have almost universally affirmed the received view that it is wrong to criticize others for wrongs we have committed ourselves" [p. 390]), but believes that the received view is mistaken. I take no position (at least in this essay) on the moral wrongness of hypocrisy, and therefore no position on the moral wrongness of criticism hypocrisy. My argument is that it is the fact of hypocrisy, rather than its badness or moral wrongness, that bears on the acceptability of the hypocrite's conclusion. My argument-or rather, my explanation of why hypocrisy is relevant-is set out in Section 5. 
what I call "projection hypocrisy," which consists in a hypocrite accusing someone else of being a hypocrite. ${ }^{19}$ This type has two versions, in one of which the hypocrisy being alleged is precisely that of which the alleging party is guilty, and in the other of which the hypocrisy being alleged is of a different sort. If the aforementioned Swaggart (a hypocritical adulterer) had accused someone else of being a hypocritical adulterer, he would have exemplified the first version of projection hypocrisy. If Swaggart had accused Peter Singer of being a hypocrite for not living up to his (Singer's) famine-relief standard, Swaggart would have exemplified the second version of projection hypocrisy.

There are interesting logical relations between the three types of hypocrisy. One can be an advocacy hypocrite without being either a criticism hypocrite or a projection hypocrite, but if one is either a criticism hypocrite or a projection hypocrite, then one must (by definition) be an advocacy hypocrite. ${ }^{20}$ Given the concepts and their inter-relations, there are five jointly exhaustive and mutually exclusive categories (meaning that every person, at any given time, falls into at least one category and no person falls into more than one category):

1. The person in question is not a hypocrite of any type.

2. The person in question is an advocacy hypocrite, but neither a criticism hypocrite nor a projection hypocrite.

3. The person in question is an advocacy hypocrite and a criticism hypocrite, but not a projection hypocrite.

4. The person in question is an advocacy hypocrite and a projection hypocrite, but not a criticism hypocrite.

5. The person in question is a hypocrite of all three types.

So much for the concept of hypocrisy. Let us turn to its application.

\section{Singer's Hypocrisy}

Do not judge, so that you may not be judged. For with the judgment you make you will be judged, and the measure you give will be the measure you get. Why do you see the speck in your neighbor's eye, but do not notice the log in your own eye? Or how can you say to your neighbor, "Let me take the speck out of your eye," while the log is in your own eye? You hypocrite, first take the log out of your own eye, and then you will see clearly to take the speck out of your neighbor's eye (Matthew 7:1-5, NRSV).

Faced with an ethical argument that requires us to give away much of our income, we might ask whether there is any point to a standard that cuts so strongly against the grain of human nature that virtually no one follows it. Over many years of talking and writing about this subject, I have found that for some people, striving for a high moral standard pushes them in the right direction, even if they—and here I include myself — do not go as far as the standard implies they should (Singer, 2010, p. 151 [emphasis added]).

\footnotetext{
19 “Project” (verb) means “transfer or attribute one’s own emotion or desire to (another person), esp. unconsciously” (New Oxford American Dictionary, 2010, p. 1396 [fourth definition]). In the psychological literature, "Projection is the process by which persons attribute personality traits, characteristics, or motivations to other persons as a function of their own personality traits, characteristics, or motivations. Furthermore, it is generally assumed that projection is a defense mechanism with which persons can reduce their anxiety concerning their possession of undesirable traits" (Holmes, 1978, p. 677 [footnote omitted]). See also APA [American Psychological Association] Dictionary of Psychology, 2019, where "projection” is defined as "the process by which one attributes one's own individual positive or negative characteristics, affects, and impulses to another person or group." ${ }^{20}$ Put formally, the predicate ' $x$ is a criticism hypocrite' is the superaltern of ' $x$ is an advocacy hypocrite', meaning that the former entails, but is not entailed by, the latter. The predicate ' $x$ is a projection hypocrite' is the superaltern of ' $x$ is an advocacy hypocrite'. The predicate ' $x$ is a criticism hypocrite' is logically independent of ' $x$ is a projection hypocrite', meaning that (1) there is no entailment relation between the two predicates, (2) both predicates can be true (of the same individual), and (3) both predicates can be false (of the same individual).
} 
It is time to make good on my claim that Singer is a hypocrite. He is, in fact, a hypocrite of all three types.

\section{Advocacy Hypocrisy}

According to multiple sources (e.g., Nasar, 1999; Specter, 1999, p. 53), Singer donates 20\% of his income to famine-relief organizations, such as Oxfam. ${ }^{21}$ This falls woefully short of the amount required by his famine-relief principle, as even he admits. He is on record (in one of America's "newspapers of record") as saying that all household income beyond $\$ 30,000$ should be donated to famine relief (Singer, 1999a). If Singer and his wife earn $\$ 100,000$ per year, then they should be donating at least $\$ 70,000$, which is $70 \%$ of their income. If they earn $\$ 250,000$, then they should be donating at least $\$ 220,000$, which is $88 \%$. If they earn $\$ 500,000$, then they should be donating at least $\$ 470,000$, which is $94 \%$. These percentages are far above the $20 \%$ he is said to donate. What is not clear is how much of Singer's wealth is distributed to the needy, for surely it is wealth, not merely income, that must be given away.

Some critics have pointed to Singer's lavish care for his elderly mother-who suffered from Alzheimer's disease-as a further example of his failure to practice what he preaches. The case of the mother has two hypocritical aspects. First, the resources Singer devoted to his mother (by one account, "tens of thousands of dollars a year" [Specter, 1999, p. 55]) could have been used to save lives and prevent suffering, as required by his famine-relief principle. Second, he has argued for many years in favor of euthanasia for incompetent adults, but was either unable or unwilling to act upon this conclusion with respect to his mother. As one critic puts it, Singer's position on euthanasia is that it is for "other people's mothers" (Berkowitz, 2000, p. 36; see also Specter, 1999, p. 55; Olasky, 2004). ${ }^{22}$

When I said at the outset of this subsection that Singer admits to being a hypocrite, I did not mean that he describes himself that way (as a hypocrite). To my knowledge, he has not done so. I meant that he admits to falling short of his moral standard, which he has advocated for nearly half a century. ${ }^{23}$ One would think that, in light of this rather blatant hypocrisy, he would long since have ceased his advocacy and apologized to his many readers for failing to practice what he preaches. Instead, he offers excuses for his failure to live in accordance with his famine-relief principle. First, he says that he "may, without any irrationality, choose to be less than totally committed to doing what [he] ought to do" (Singer, 1999b, p. 309). Second, he suggests

\footnotetext{
${ }^{21}$ Specter notes, wryly, that "Singer has certainly done nothing to impoverish himself" (p. 53). A reporter for the South China Morning Post, who interviewed Singer, says that he (Singer) "has largely lived by his own moral code. He has been a vegetarian for 45 years and, for the past four decades, has donated to charity between 10 per cent and 33 per cent of his income, and aims to eventually reach 50 per cent” (Baker, 2015); see also Southan, 2017, p. 13, who quotes Singer as saying that even if he (Singer) donated half his income, “that still isn’t anywhere near the point of marginal utility.” Singer was born on 6 July 1946, so he was almost 69 years old when Baker's story appeared. One wonders when he expected (or when he expects) to "reach 50 per cent."

${ }^{22}$ To be fair to Singer, the decisions about his mother's care were not his alone to make. His sister shared the decision-making. Singer told Jo Baker (2015) that if he had been "in sole charge," his mother "would probably have died six months earlier than she did." We are not told how this would have been accomplished.

On a related note, Stuart Rachels (2014, p. 474) has argued that "the most important practical implication of Singer's [famine-relief] argument" is that "it requires us to be childless." If this is correct, then Singer, who must be presumed to accept the implications of his moral principle, is an advocacy hypocrite two times over, for he has two children. Singer, however, appears not to share Rachels's view about what his (Singer's) moral principle implies, for, in answer to a question about whether he "think[s] it is wrong for individuals in the developed world to have children, when they know that this will make them more partial and contribute less to the overall good," Singer answered, “No, I don't” (Singer, 2016b, p. 75). Unfortunately, Singer neither supported his negative answer to the question nor explained why he is not committed-as Rachels suggests he is-to an affirmative answer.

${ }^{23}$ This fact led Peter Berkowitz (2000, p. 28) to say that Singer "stands condemned as morally indecent by his own simple formula."
} 
that he is weak-willed. ${ }^{24}$ Third, his friend and collaborator Helga Kuhse says that "it is very likely that Peter Singer is approximating his ethical ideal far more closely than many, if not most, of his critics” (Kuhse, 2002, p. $12) .^{25}$

It must be said—respectfully — that these are flimsy excuses. In none of the essays in which Singer sets out his famine-relief principle does he indicate that his readers may "choose to be less than totally committed to doing what [they] ought to do.” In none of the essays does Singer say that what his principle demands is "approximating [the] ethical ideal more closely than [others]." It is particularly rich for Singer to say that he is doing better (morally speaking) than his critics, for the standard is his, not his critics'. Singer is saying, in effect, "I come closer to living in accordance with my principle than you [the critics] do." Neera Badhwar is not the only person who finds this disingenuous:

Singer's actions make it obvious that he is sincere in his advocacy and tries to live up to his ideals. He gives away far more of his income than almost anyone-between 20 percent and 25 percent, according to various sources. But this is a far cry from what he thinks people should give: everything they don't require for their own or their family's basic needs. Singer suggests that he would give more if others did, but this is a feeble excuse. It is precisely when others are giving too little that his giving more is more needed, as he himself urges in response to those who object that they should not have to do more than their 'fair' share just because others are doing less (Badhwar, 2006, p. 90 [italics in original; footnotes omitted]).

Instead of excusing his behavior, Singer should forthrightly admit to being a hypocrite (using that very term) and accept whatever opprobrium ensues. Perhaps reflection on the impracticability of his principle-as demonstrated by his failure to conform to it-would cause him to retract it and to advocate a less demanding principle, one that he as well as his "critics" can live up to. ${ }^{26}$

To Singer's credit, he does consider (and reject) at least one excuse for his failure to abide by his famine-relief principle. The excuse is that abiding by the principle goes against the grain of his nature as a human being. Singer writes:

[T] o be widely accepted and acted upon, as we wish them to be, moral rules have to be attuned to our evolved human nature, with all its quirky relics of our tribal past. If we fail to take into account the biases that . . make it difficult to persuade us to give anything like the same weight to the interests of distant people we cannot identify as we give to the interests of people we can see or name, then the moral rules we advocate will do little good, because few people will follow them. I am in a different situation, however, when I am making my own decision about how much to give. I can’t

\footnotetext{
${ }^{24}$ According to Helga Kuhse (2002, p. 12), Singer, “when asked by a German magazine to list his greatest weaknesses, . . . accorded first place to 'selfishness.”"

${ }^{25}$ Kuhse adds, puzzlingly, that "Singer has never claimed that his life matches the strict dictates of his ethics” (p. 12). This raises an important question: Does hypocrisy require, in addition to not practicing what one preaches, that one claim that one does practice what one preaches? Did Jimmy Swaggart, the consummate hypocrite, claim (in a sermon, for example) that he practiced what he preached? I am unaware that he did. In fact, I am fairly sure that he did not.

${ }^{26}$ I am aware that Singer has a weak principle as well as a strong principle, but he continues to insist that the strong principle is the correct one.

One possible explanation of Singer's hypocrisy is what Daniela Dover (2019, p. 411) calls "moral resignation about the self." She writes (2019, p. 411, n. 27):

Think of the utilitarian philosophy professor who believes that she ought to be out alleviating pain rather than luxuriating in her armchair. Though she knows she will never do what she sincerely believes morality requires of her, she nevertheless hopes to inspire a few of her students to do so. It's a commonplace that we expect better of some people than we do of others. It is equally possible to expect better of certain others than one does of oneself, succumbing to a kind of fatalism about one’s own character without becoming equally pessimistic about the character of others.
}

It is difficult to read this passage without thinking of Singer. 
then appeal to my own human nature as a reason for not doing what I would otherwise judge that I ought to do (Singer, 2010, p. 153 [ellipsis added]).

There is a difference, Singer seems to be saying, between advocating an action and performing an action (though advocacy is itself an action). When I advocate an action, I must take into account the limitations (if any) of my audience. When I perform an action, there is no audience. There is only me, deciding what to do. Singer continues:

As the French existentialist philosopher Jean-Paul Sartre famously pointed out, when I ask myself what I ought to do, I am free. It would simply not be true for me to say: “I can’t give a thousand dollars to help strangers in Africa, because I'm human and humans are less concerned about distant anonymous strangers than they are about people nearby whom they know.” How does that stop me from going to Oxfam's website, filling in my credit card details, and donating $\$ 1,000$ ? How does it even provide a reason against it? I would, to use one of the existentialists' favorite terms of condemnation, be "lacking in authenticity" if I were to appeal to human nature as a reason for not doing what I see to be right, and what nothing is preventing me from doing, except that I do not choose to do it (Singer, 2010, p. 153 [italics in original]).

Like most thoughtful people, Singer wishes to avoid inauthenticity, so he renounces an excuse that would pin that label on him. He should similarly wish to avoid hypocrisy, which is a form of inauthenticity. To do so, he should either stop preaching or start practicing. ${ }^{27}$

\section{Criticism Hypocrisy}

Singer has not hesitated to criticize those who fall short of his moral standard. "Criticize" is actually too mild a term in this context, for Singer's criticisms border on hectoring. ${ }^{28}$ He has said, for example, that "it should be seen as a serious moral failure when those with ample income do not do their fair share toward relieving global poverty" (Singer, 2006 [emphasis added]). ${ }^{29}$ He then adds, as if sensing the hypocrisy of his criticism, "it may be best to refrain from criticizing those who achieve the fair-share level." In 1999, in an essay written for a popular audience, he wrote that those who fail to make the requisite sacrifices for strangers "are failing to live $a$ morally decent life" (Singer, 1999a [emphasis added]). ${ }^{30}$ In 2010, Singer wrote that "if you do not donate to aid agencies, you are doing something wrong” (Singer, 2010, p. 16). He even adverts to the goodness (vel non) of those who fall short of his standard: "[I]n order to be good people, we must give until if we gave more, we would be sacrificing something nearly as important as the bad things our donation can prevent” (Singer, 2010, p. 140). The key word here is “we," for that obviously includes Singer.

\footnotetext{
27 In an essay on the "significance of hypocrisy," Scott Aikin suggests a possible reply to an "impracticability argument," such as that being made herein. The reply is that, in the case at hand, individual action is inefficacious. Action, to accomplish the arguer's goals, must be coordinated. See Aikin, 2008, pp. 165-167. This reply, which Aikin calls “tu quoque judo,” is unavailable to Singer, for Singer has emphasized repeatedly-over the course of nearly 50 years - that one's obligation to relieve famine is not contingent on what others are doing. One may, and should, relieve famine even if nobody else is doing so.

28 "Hector" (verb) means "talk to (someone) in a bullying way" (New Oxford American Dictionary, 2010, p. 805). Other terms that come to mind in this connection are "admonish,” "berate,” “chide,” “chastise,” "censure,” "blame,” "denounce,” "reproach,” “condemn,” "reprimand,” and "rebuke.” William Godwin put it best in 1798: "There is scarcely any tyranny more gross, than that of the man who should perpetually intrude upon us his crude and half-witted advices, or who, not observing when, in point of strength and clearness, he had done justice to his own conception, should imagine it to be his duty to repeat and press it upon us without end" (Godwin, 1971 [1798], p. 87).

${ }^{29}$ In his original 1972 essay, Singer said that "the way people in relatively affluent countries react to a situation like that in Bengal [whose residents were stricken with famine as a result of poverty, a cyclone, and a civil war] cannot be justified" (Singer, 1972, p. 230 [emphasis added]). He later elaborated: "we ought to give the money away, and it is wrong not to do so" (p. 235 [emphasis added]).

30 A decade later, he said much the same thing: "If I am correct, the vast majority of us who live in developed nations are not living an even minimally decent ethical life” (Singer, 2009a [emphasis added]).
} 
As late as 2016, in the preface of the book in which he reprints his 1972 essay, Singer laments the fact that "very few of us are living fully ethical lives" (Singer, 2016a, p. xvii). And so it goes, ad nauseam. To quote an anonymous reviewer in the Edinburgh Review nearly two centuries ago, Singer is "ever ready to mistake [his] own decisions for the voice of reason" (Anonymous, 1824, p. 170). He seems oblivious to the fact that different people, no less sensitive, knowledgeable, intelligent, and well-meaning than he is, can (and do) arrive at different conclusions regarding the extent of the duty of beneficence. This is hypocrisy with a vengeance. ${ }^{31}$

\section{Projection Hypocrisy}

It would be bad enough if Singer were only a criticism hypocrite (which entails, as we saw, being an advocacy hypocrite), but he doesn't stop there. He also criticizes people whom he believes to be hypocrites. In 2004, Singer published a 280-page book entitled The President of Good \& Evil: The Ethics of George W. Bush. In this book, Singer repeatedly accuses then-President George W. Bush of hypocrisy for not living up to what Singer considers to be his (Bush's) moral standards. Singer doesn't always use the word "hypocrisy," but it is clear that this is his accusation. He says, for example, that "Bush's support for the death penalty, in the face of evidence that it is not an effective deterrent, plus the evidence that the American system of justice allows some innocent people to be executed, is not consistent with his professed ethic of respect for innocent human life" (Singer, 2004, p. 58 [emphasis added]). Sometimes Singer does use the word "hypocrisy.” He says, for example, that President Bush's "protection of the steel industry and his signature on a law authorizing the largest-ever subsidies to American farmers shows his strong rhetoric about free trade to be a brutal hypocrisy that is driving millions of impoverished farmers in other countries deeper into poverty" (Singer, 2004, p. 224 [emphasis added]). Not just hypocrisy, mind you, but brutal hypocrisy!

Singer does not (alas) limit his accusations of hypocrisy to former President Bush. He has also accused "America” and "western nations" of hypocritical behavior, the former for not living up to its ideals of equality, liberty, and rights-possession (see Singer, 2007), ${ }^{32}$ the latter for criticizing Japan’s practice of whaling while themselves "inflict[ing] so much unnecessary suffering on animals—-through culling (the Australian slaughter of kangaroos), hunting and factory farms” (Singer, 2008). It takes a certain amount of gall to project one’s own moral failings onto others, but Singer manages to do it.

\section{Why (and How) Hypocrisy Matters}

Discordance between life and work is more common than otherwise and does not invalidate a person's ideas. But in areas of uncertainty we cast a wide net for evidence of credibility and when we see people advocating practices or beliefs that they themselves would find irksome, or even intolerable, it makes us doubt the soundness of their advocacy (Posner, 2001, p. 308).

One cannot convincingly ask others to [abstain from meat] if one does not [abstain from meat] oneself (Singer, 1980, p. 337).

\footnotetext{
31 Singer has also been severely critical of governments, especially the United States government. In 1979, he wrote: “One quarter of one percent of GNP is a scandalously small amount for a nation as wealthy as the United States to give” (Singer, 1979, p. 179 [emphasis added]).

32 Singer believes that the detention of "enemy combatants" (he uses quotation marks because he disputes the characterization) by the United States government is inconsistent with American values as expressed in the nation's founding documents. According to Singer (2007), “If America would only follow [Tom Paine’s] advice [to defend the liberty of one's enemies], it might really be a beacon of hope and a shining example. But as long as [the government of the United States] continues to hold and abuse prisoners without giving them a fair trial, America's professed ideals will continue to sound to the rest of the world like the deepest hypocrisy."
} 
Every deductive argument has two components, one formal and the other substantive. The formal component is an assertion, by the arguer, that the conjunction of the argument's premises is logically inconsistent with the negation of the argument's conclusion-in other words, that the premises entail the conclusion. The substantive component is an assertion, also by the arguer, that the premises are true. Suppose, to use the earlier example, that I argue as follows:

1. All men are mortal.

2. Socrates is a man.

Therefore,

3. Socrates is mortal.

I am asserting that the following set of propositions is logically inconsistent:

- $\quad$ All men are mortal.

- Socrates is a man.

- Socrates is not mortal.

Logical consistency is an objective relation between propositions, though rational people sometimes disagree whether a given set of propositions is logically consistent. ${ }^{33}$ In the example provided (concerning Socrates), no rational person can believe that the set is logically consistent, and therefore no rational person can accept (as true) all three propositions. It follows that every rational person must reject (as false) at least one of the three propositions. I, the arguer, may reject the third proposition, but someone else, no less rational than I am, may reject the first or the second proposition. ${ }^{34}$ Notice that none of the three propositions is prescriptive (i.e., action-guiding) in nature. All are descriptive (fact-stating).

Singer's argument differs from this example in a fundamental way: it has a prescriptive conclusion. To avoid violating Hume's Law, ${ }^{35}$ therefore, it must have at least one prescriptive premise, and indeed it does. The prescriptive premise is the general principle that one ought to prevent very bad things from happening, so long as one does not, thereby, sacrifice anything morally significant. (It also has an evaluative premise, namely, the proposition that suffering and death from lack of food, shelter, and medical care are very bad). It is because Singer's argument has a prescriptive conclusion—and only because it has a prescriptive conclusion— that facts about Singer become relevant to the acceptability of his conclusion. For notice: Singer is not merely asserting that his premises are logically inconsistent with the negation of his conclusion; he is not, in other words, engaged solely in conceptual analysis. He is asserting the truth, or at least the acceptability, of his premises. But, as we saw, just because Singer rejects the negation of his conclusion, there is no reason why everyone must do so. A rational person (recall Quine’s dictum) may well reject one of Singer's premises.

When Singer is pressed on this point, he dissembles. According to Jeff Sharlet, writing in the Chronicle of Higher Education, Singer defends himself from the charge of advocating baby-killing as follows: "The sentence that's always quoted about the disabled baby. . . . If you look at it in context, you see that I'm putting

\footnotetext{
${ }^{33}$ To cite just one example, J. L. Mackie (1955) famously argued that the following set of propositions is logically inconsistent: (1) there is a god; (2) God is omnipotent; (3) God is wholly good; (4) evil exists; (5) good is opposed to evil, in such a way that a good thing always eliminates evil as far as it can; and (6) there are no limits to what an omnipotent thing can do. Alvin Plantinga and others have disputed this claim.

34 As W. V. Quine famously put it, “Any statement can be held true come what may, if we make drastic enough adjustments elsewhere in the system” (Quine, 1951, p. 40).

35 “[A]s this ought, or ought not, expresses some new relation or affirmation, 'tis necessary that it shou'd be observ'd and explain'd; and at the same time that a reason should be given, for what seems altogether inconceivable, how this new relation can be a deduction from others, which are entirely different from it” (Hume, 1739-1740, Book III, Part I, Sect. I [italics in original]).
} 
forward the implication of a position" (quoted in Sharlet, 2000). This suggests that all Singer is doing is pointing out, in the manner of a disinterested spectator, that a particular set of propositions is logically inconsistent. But when he argues, he is doing more than that. He is rejecting one of the propositions (namely, the denial of the conclusion). Singer, in other words, is not engaged in conceptual analysis for its own sake, or for the light that it may shed on our concepts; he is taking a stand on a normative issue. He is not a detached or disinterested observer (and reporter) of an activity; he is a participant in that activity. It is therefore disingenuous of Singer to defend himself from criticism by pointing out that all he is doing is drawing out the implications of a principle or position. He is advocating, endorsing, taking a stand. ${ }^{36}$ Thus, Sharlet is mistaken when he writes:

[Singer's] critics seem to have forgotten that philosophy need not be autobiographical. The validity of Mr. Singer's ideas doesn't depend on his qualities as a son or his personal failings as a utilitarian. His rigor isn't so much in his behavior as it is in his willingness to contemplate fully the end of a line of reasoning, even if he doesn't go there himself (Sharlet, 2000).

Sharlet is certainly correct that philosophy need not be autobiographical. Conceptual analysis (or clarification), which is "the most distinctively philosophical of enterprises" (Feinberg, 1984, p. 17), is not autobiographical. But Singer is doing more than analyzing or clarifying concepts; he is arguing. He is in the arena. Singer can't have it both ways. Either (1) he is taking a stand (on a normative matter), in which case he "owns" whatever controversy it generates, or (2) he is not taking a stand, in which case he is merely interpreting the world and not trying to change it (recall Marx's 11th thesis on Feuerbach). What Singer can't do is take a stand while remaining aloof from the resultant controversy.

Suppose, then, that I have read one of Singer's famine-relief essays and am wondering whether to accept his conclusion, which, as we saw, prescribes an act. Is it unreasonable of me to inquire into its practicability? In other words, is it unreasonable of me to ask whether the act prescribed by his conclusion is able to be done or put into practice successfully? ${ }^{37}$ After all, Singer isn't asking me merely to believe something; he is asking me to do something. To put it in old-fashioned terms, he is engaged in practical reasoning (or argumentation), not theoretical reasoning. It seems eminently appropriate for me, therefore, to ask: Is what Singer is asking me to do doable? I reason as follows:

1. A moral principle is acceptable (i.e., worthy of being accepted $^{38}$ ) only if it is practicable (i.e., able to be done or put into practice successfully). ${ }^{39}$

2. A moral principle is practicable only if it is put into practice successfully by the person who is most highly motivated to put it into practice.

Therefore,

3. A moral principle is acceptable only if it is put into practice successfully by the person who is most highly motivated to put it into practice (from 1 and 2).

4. The person who is most highly motivated to put a moral principle into practice is the person who advocates it (i.e., publicly recommends or supports it).

\footnotetext{
36 "Moralizing is not merely a matter of judgment; when push comes to practical shove, we must be prepared to perform those actions to which we have given praise and refrain from the sorts of behavior that we have criticized-even (or perhaps especially) if doing so would be inconvenient” (Isserow \& Klein, 2017, p. 209).

37 This is the first definition of "practicable" (adjective) in the New Oxford American Dictionary, p. 1372.

38 This is the first definition of "acceptable" (adjective) in the Oxford American Dictionary and Language Guide, p. 6.

39 " [F]rom a pragmatic perspective, it is only by judging the consequence of attempting to embody certain ethical principles in our lives and social arrangements that those principles can be justified or refuted” (Altman, 1983, p. 233).
} 
Therefore,

5. A moral principle is acceptable only if it is put into practice successfully by the person who advocates it (from 3 and 4).

6. Peter Singer advocates a moral principle (his famine-relief principle).

Therefore,

7. Peter Singer's famine-relief principle is acceptable only if Peter Singer puts it into practice successfully (from 5 and 6).

8. Peter Singer does not put his famine-relief principle into practice successfully. Therefore,

9. Peter Singer's famine-relief principle is unacceptable (i.e., unworthy of being accepted) (from 7 and 8).

By a series of four valid inferences, I have arrived at a conclusion about the acceptability of Singer's famine-relief principle that is based on a fact about Singer, namely, his hypocrisy (expressed by proposition 8). Singer's hypocrisy matters because it bears on the practicability of his moral principle (and the conclusion that follows from it). Practicability may be irrelevant to theoretical reasoning, such as the example concerning Socrates, but it is relevant, and indeed important, to practical reasoning. People who don't practice what they preach tell the rest of us, in no uncertain terms, that what they are preaching is unable to be done or put into practice successfully. They are living proof—the embodiment, if you will—of the impracticability of their prescriptions. Nietzsche may have exaggerated somewhat when he said that "The only possible criticism of a philosophy, the only criticism that proves anything at all, is trying to see if one can live by it,” but surely inability to live by one's philosophy is a criticism of it. ${ }^{40}$

\section{Conclusion}

[Y]ou cannot expect people to take seriously your moralizing pronouncements, or even to listen to them, if it is clear to them at the time that you do not take those pronouncements seriously yourself; and pronouncements that you cannot expect others to take seriously become pointless (Wallace, 2010, p. 315, n. 16).

[I] doubt whether preaching what one does not practice would be very effective (Singer, 1972, p. 240). ${ }^{41}$

My aim in writing this essay is not, as may seem to be the case, to pick on Peter Singer, for surely he is not the only philosophical (or academic) hypocrite. ${ }^{42}$ It is to use him as the occasion for discussing an important issue, namely, whether characteristics of the arguer bear on the acceptability of his or her conclusion. I have argued that at least one characteristic — hypocrisy_does bear on acceptability. When I am presented with an argument for a prescriptive (i.e., action-guiding) conclusion, I naturally wonder whether the conclusion is practicable

\footnotetext{
${ }^{40}$ If we think of Singer as endorsing a product, we should ask the question we ask of any product spokesperson, namely, "Do you use the product? If not, why not?”

${ }^{41}$ See also Singer, 1975, p. 243 ("[S]omeone whose conduct is inconsistent with his professed beliefs will find it difficult to persuade others that his beliefs are right; and he will find it even more difficult to persuade others to act on those beliefs") and Singer, 2009b, p. 231 (same quotation, but with gender-neutral pronouns). Singer seems aware (albeit dimly) that his hypocrisy bears on the acceptability of his conclusion. A decade ago, he wrote that, "Since our students may ask us how well we are living up to the moral arguments we are presenting to them, failing to meet the challenge could lead to awkward moments in class" (Singer, 2009a). This is puzzling. Why would it be awkward if the alleged hypocrisy were irrelevant? Wouldn't Singer simply explain to his students that his failure to "live up to the moral arguments he is presenting to them" has no bearing on either (1) the validity of his argument, (2) the truth (or acceptability) of his premises, or (3) the truth (or acceptability) of his conclusion? Whence the awkwardness?

42 See Schwitzgebel \& Rust, 2014, p. 314 (reporting that, with respect to charitable donation, “[e]thicists showed the weakest relationship between expressed normative view and self-reported behavior, non-philosophers the strongest”) and Green, 2015.
} 
(doable, feasible, livable). In answering this question, I look to see whether the arguer, who is presumed to be highly motivated to accept (and act upon) the conclusion, practices what he or she preaches. If the answer is "no," then I have reason to believe that the standard is impracticable, and therefore unacceptable. ${ }^{43}$ Hypocrisy matters. Philosophers should no longer dismiss, as irrelevant, student queries about an arguer's personal behavior or lifestyle. Instead, philosophers should explain to their inquiring students just why (and how) hypocrisy matters.

\section{Acknowledgments}

This essay is dedicated to Peter Singer, in the forlorn hope that he will cease preaching what he cannot (or will not) practice. I sincerely believe that his hypocrisy on the question of famine relief (documented at length herein) has had two baleful effects, the first straightforward and the second insidious: it has harmed the cause of famine relief (by demonstrating the impracticability of Singer's conclusion) and it has brought ridicule and shame to the discipline of philosophy—of which, for nearly 50 years, Singer has been a prominent (perhaps the most prominent) member.

\section{References}

Aikin, S. F. (2008). Tu quoque arguments and the significance of hypocrisy. Informal Logic, 28, 155-169.

Alterman, E. (2004). The Hollywood campaign. The Atlantic Monthly, 294, 73-88.

Altman, A. (1983). Pragmatism and applied ethics. American Philosophical Quarterly, 20, 227-235.

Anonymous. (1824). Review of Traité des preuves judiciaires, by E. Dumont. The Edinburgh Review, 40, 169-207.

APA [American Psychological Association] dictionary of psychology. (2019). Online.

Atkinson, C. M. (1905). Jeremy Bentham: His life and work. London: Methuen \& Co.

Badhwar, N. K. (2006). International aid: When giving becomes a vice. Social Philosophy \& Policy, 23, 69-101.

Baker, J. (2015). Philosopher Peter Singer on why all men are not created equal. South China Morning Post, May 9.

Benn, P. (1993). What is wrong with hypocrisy? International Journal of Moral and Social Studies, 8, 223-235.

Berkowitz, P. (2000). Other people’s mothers: The utilitarian horrors of Peter Singer. Review of A Darwinian left: Politics, evolution, and cooperation, by P. Singer, and Practical ethics, 2nd ed., by P. Singer. The New Republic, 222, 27-37.

Brandt, R. B. (1959). Ethical theory: The problems of normative and critical ethics. Englewood Cliffs, NJ: Prentice-Hall.

Cohen, M. R., \& Nagel, E. (1962). An introduction to logic. New York: Harcourt, Brace \& World.

Crisp, R., \& Cowton, C. (1994). Hypocrisy and moral seriousness. American Philosophical Quarterly, 31, 343-349.

Dover, D. (2019). The walk and the talk. Philosophical Review, 128, 387-422.

Feinberg, J. (1984). The moral limits of the criminal law, vol. 1, Harm to others. New York: Oxford University Press.

Godwin, W. (1971 [1798]). Enquiry concerning political justice. Edited by K. C. Carter. Oxford: Clarendon Press.

Green, E. (2015). Philosophers are hypocrites. The Atlantic, 315, 33.

Hare, R. M. (1981). Moral thinking: Its levels, method, and point. Oxford: Clarendon Press.

Holmes, D. S. (1978). Projection as a defense mechanism. Psychological Bulletin, 85, 677-688.

Hume, D. (1739-1740). A treatise of human nature.

Isserow, J., \& Klein, C. (2017). Hypocrisy and moral authority. Journal of Ethics and Social Philosophy, 12, 191-222.

Jamieson, D. (1999). Singer and the practical ethics movement. In D. Jamieson (Ed.), Singer and his critics. Malden, MA: Blackwell Publishers.

Kekes, J. (2002). On the supposed obligation to relieve famine. Philosophy, 77, 503-517.

Kittay, E. F. (1982). On hypocrisy. Metaphilosophy, 13, 277-289.

Kuhse, H. (2002). Introduction: The practical ethics of Peter Singer. In H. Kuhse (Ed.), Unsanctifying human life: Essays on ethics, by P. Singer. Malden, MA: Blackwell Publishers.

\footnotetext{
${ }^{43}$ Richard Brandt has some helpful advice: “Ask yourself when you think a person 'really believes' a moral principle or has a moral conviction, and you will find that you think 'actions speak louder than words.' We judge by whether he shows motivation to live by his conviction, by whether at least symptoms of inner conflict or remorse are visible when he doesn't live by it” (Brandt, 1959, p. 217 [italics in original]).
} 
Mackie, J. L. (1955). Evil and omnipotence. Mind, n.s., 64, 200-212.

Mackie, J. L. (1967). Fallacies. In P. Edwards (Ed.), The encyclopedia of philosophy, vol. 3, pp. 169-179. New York: Macmillan Publishing Company.

Marx, K. (1845/1888). Theses on Feuerbach.

Matthew 7:1-5, NRSV.

Nasar, S. (1999). Princeton's new philosopher draws a stir. The New York Times, April 10.

New Oxford American dictionary. (2010). 3rd ed. New York: Oxford University Press.

Nietzsche, F. (1990). Schopenhauer as educator. In W. Arrowsmith (Ed.), Unmodern observations. New Haven \& London: Yale University Press.

Olasky, M. (2004). Blue-state philosopher. World, November 27.

The Oxford American dictionary and language guide. (1999). New York: Oxford University Press.

Posner, R. A. (2001). Public intellectuals: A study of decline. Cambridge and London: Harvard University Press.

Quine, W. V. (1951). Two dogmas of empiricism. The Philosophical Review, 60, 20-43.

Rachels, J. (1981). Sociobiology and the 'escalator' of reason. Review of The expanding circle: Ethics and sociobiology, by P. Singer. The Hastings Center Report, 11, 45-46.

Rachels, S. (2014). The immorality of having children. Ethical Theory and Moral Practice, 17, 567-582.

Schwitzgebel, E., \& Rust, J. (2014). The moral behavior of ethics professors: Relationships among self-reported behavior, expressed normative attitude, and directly observed behavior. Philosophical Psychology, 27, 293-327.

Sharlet, J. (2000). Why are we afraid of Peter Singer? The Chronicle of Higher Education, 46, March 10.

Singer, P. (1972). Famine, affluence, and morality. Philosophy \& Public Affairs, 1, 229-243.

Singer, P. (1975). Animal liberation. New York: Avon Books.

Singer, P. (1977). Reconsidering the famine relief argument. In P. G. Brown and H. Shue (Eds.), Food policy: The responsibility of the United States in the life and death choices. New York: The Free Press.

Singer, P. (1979). Practical ethics. Cambridge: Cambridge University Press.

Singer, P. (1980). Utilitarianism and vegetarianism. Philosophy \& Public Affairs, 9, 325-337.

Singer, P. (1999a). The Singer solution to world poverty. The New York Times Magazine, September 5.

Singer, P. (1999b). A response. In D. Jamieson (Ed.), Singer and his critics. Malden, MA: Blackwell Publishers.

Singer, P. (2001). Writings on an ethical life. New York: Ecco.

Singer, P. (2002). Unsanctifying human life: Essays on ethics. Edited by H. Kuhse. Malden, MA: Blackwell Publishers.

Singer, P. (2004). The president of good \& evil: The ethics of George W. Bush. New York: Dutton.

Singer, P. (2006). What should a billionaire give—and what should you? The New York Times Magazine, December 17.

Singer, P. (2007). America the hypocritical. Project Syndicate, February 14.

Singer, P. (2008). Harpooned by hypocrisy. The Guardian, January 19.

Singer, P. (2009a). America’s shame. The Chronicle of Higher Education, 55, March 13.

Singer, P. (2009b). Animal liberation: The definitive classic of the animal movement. Updated ed. New York: HarperCollins Publishers.

Singer, P. (2010). The life you can save: How to do your part to end world poverty. New York: Random House.

Singer, P. (2011). Practical ethics. 3rd ed. Cambridge: Cambridge University Press.

Singer, P. (2016a). Famine, affluence, and morality. New York: Oxford University Press.

Singer, P. (2016b). Twenty questions. Journal of Practical Ethics, 4, 67-78.

Smilansky, S. (1994). On practicing what we preach. American Philosophical Quarterly, 31, 73-79.

Southan, R. (2017). Peter Singer, R. M. Hare, and the trouble with logical consistency. Essays in Philosophy, 18, 1-26.

Specter, M. (1999). The dangerous philosopher. The New Yorker, 75, 46-55.

Szabados, B. (1979). Hypocrisy. Canadian Journal of Philosophy, 9, 195-210.

Taylor, G. (1981). Integrity. The Aristotelian Society, supp. vol. 55, 143-159.

Toolis, K. (1999). The most dangerous man in the world. The Guardian, November 6.

Turner, D. (1990). Hypocrisy. Metaphilosophy, 21, 262-269.

Wallace, R. J. (2010). Hypocrisy, moral address, and the equal standing of persons. Philosophy \& Public Affairs, 38, 307-341. 